\title{
Once Upon A Time in the Fortune 500: How Storytelling Encouraged Businesses to Take a Second Look at Blogs
}

\author{
Stephanie Jacobsen \\ Bridgewater State University \\ Nora Ganim Barnes \\ University of Massachusetts Dartmouth
}

In the early 2000s about one third of the Fortune 500 hosted corporate blogs. By 2014, that number dropped significantly. Since then, the popularity of "storytelling" has been widely discussed by marketers. As Marketing began to use storytelling as a strategy, blogs began to mimic the structure of stories. The top companies in the 2018 Fortune 500 now have corporate blogs using this framework. Did storytelling help the Fortune 500 to rediscover blogging? This research investigates the use of storytelling as an impetus to blog and how the blogging of today has evolved away from the interactive experience first expected.

Keywords: Blogging, Social Media, Storytelling, Online Engagement

\section{INTRODUCTION}

In 2016, Jacobsen and Barnes released a paper called "The Unfortunate Decline of Blogging among the Fortune 500: The Downside of Adopting Substitute Innovations" (Jacobsen and Barnes, 2016). In this paper, they discussed how the use of blogging was decreasing among the Fortune 500. At the time, consumers were flocking to other social media platforms that were quicker and easier to use (Twitter, Instagram etc.). Because of this, companies began to interact with their consumers using some of the newer communications tools that promised speed and engagement. These tools did not offer many of the attributes that had made blogs favorable including unlimited space, control, and the ability to craft clear and meaningful messages. It did not take long before those platforms that promised faster and easier roads to engagement, were deemed unsuitable substitutions for the oldest social media tool, blogging.

In an attempt to generate messages that better connect with a target audience, organizations have recently shifted their focus to storytelling. Recent articles in Forbes (Whitler, 2018; Davis, 2018; Olenski, 2018; Ghanadan, 2018; Forbes Communication Council, 2018; Otremba, 2018) and Adweek (Gianatasio, 2018; Santore, 2018) discuss, how and why organizations are using and should be using storytelling to reach a larger audience. The author of one such article states: 
"Society is obsessed with consuming and creating content-we simply can't get enough of it. Every second, there is more content being produced than ever before. In a world where attention is the most valuable commodity, if you aren't producing solid storytelling, it's like shouting into the wind"' (Santore, 2018).

While, this recent push towards storytelling is important, it may also seem familiar. This is because when blogging was growing in popularity originally (2000's), storytelling was the focus of many marketing researchers (Vincent, 2002; Papadatos, 2006; Woodside, Sood \& Miller, 2008). The strategy of using storytelling never really went away, but it has changed in terms of execution. Blogging was originally an easy way to craft any story, and without a limit of time or space. While blogging was limited to less than $30 \%$ of the Fortune 500 before 2012 and then began declining in 2014, other options were emerging for faster and more visual storytelling (ie. Snapchat, Facebook and Instagram stories, YouTube videos).

Since blogging has been on the decline, researchers have not explored the possibility that storytelling could help blogging increase in popularity again. This study begins with a review of the storytelling literature, a brief look at blogging, research questions, and methodology. This is followed by the results, discussion and conclusion.

\section{LITERATURE REVIEW}

\section{Storytelling}

Tell me a fact and I'll learn. Tell me the truth and I'll believe But tell me a story and it will live in my heart forever. Indian Proverb

Storytelling has existed essentially since humans developed the ability to tell a tale. Long before we were able to write, we listened to those around us, using memory as the only way to learn. The earliest evidence of storytelling was discovered in France in 1940. In the Pyrenees Mountains, there is a series of cave paintings that date back to between 15,000 and 13,000 B.C (The Big Fish Blog, 2012). From Gilgamesh to Aesop's fables, stories have been passed down and shared throughout villages, towns, cities and countries. Storytelling has proven to be an effective way to communicate.

In 2000, a pioneering book was released proclaiming "The End of Business as Usual” (Levine et. al.) and spoke about the new opportunities and challenges posed by the Internet specifically for marketing. In the introduction the authors write: "Hypertext is inherently nonhierarchical and anti-bureaucratic. It does not reinforce loyalty and obedience. It encourages stories."

That was followed by Scoble and Isreal (2006) in Naked Conversations: How Blogs Are Changing the Way Businesses Talk with Consumers. They see blogs as essential for businesses in what they describe as the "social media revolution." They point to the ability of this tool to have conversations and share experiences in a way that humanizes a company and engages consumers. Baker Brand Communications released a story telling series (2018) in which they assert that stories engage the brain more than data and stimulate emotional and biological responses.

In 2010 the popular business magazines began addressing storytelling saying that the format is the catalyst for passionate and engaged consumers. Fortune Magazine (2010) cites SVP Steve Rubel from Edelman Public Relations firm as being responsible for the term "transmedia storytelling" and advocating that businesses find a way to use storytelling across channels. The article concludes that businesses need to develop compelling narratives to engage consumers. But the real rise in the use of storytelling to promote brands and companies is more recent.

A Harvard Business Review article (Monarth, 2014) discussed the work of Neuroeconomist Paul Zak whose research indicates that our brains produce the stress hormone cortisol during the tense moments in a story and the good feeling dopamine with a happy ending to a story. With these chemicals in place, passion, trust and sympathy are ignited. 
The same article suggests that the most effective storytelling follows the structure proposed by Gustav Freytag in the 18th century. Freytag's Pyramid arranges stories into five parts including an exposition, rising action, climax, falling action and the final outcome.

\section{FIGURE 1 \\ FREYTAG'S PYRAMID}

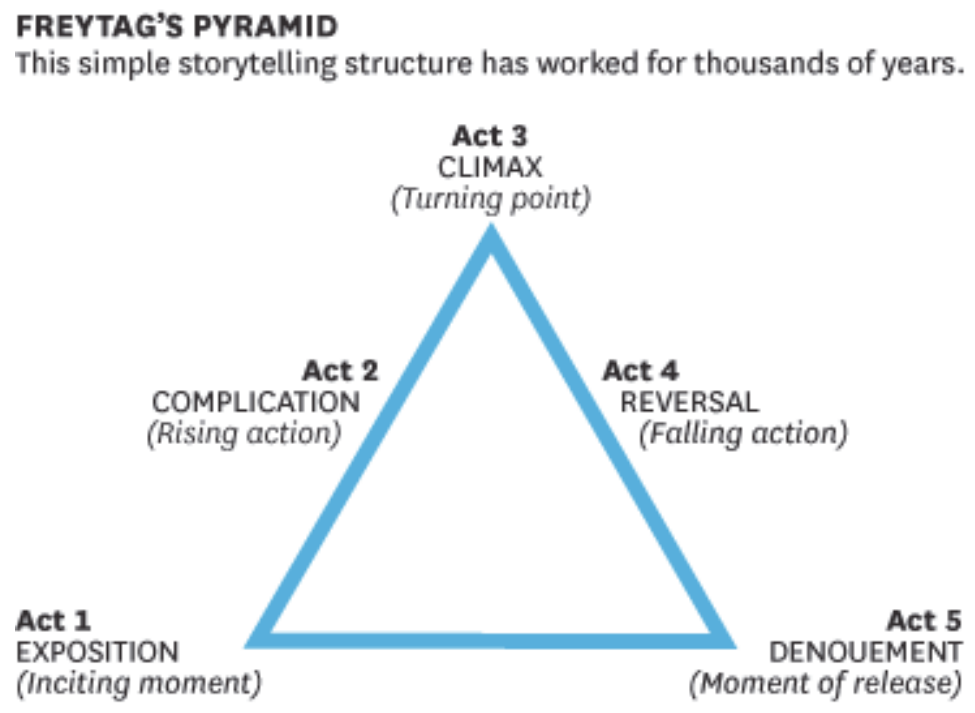

Supporting this, research in 2014 (Quesenberry) coded commercials for plot development and found that regardless of content, the structure of the content predicted its success. The structure suggested by Freytag is duplicated in the most effective corporate blogs.

Even a recent study comparing lecture to storytelling as a format, found that while lectures are likely to put the audience to sleep, storytelling increases your ability to connect with the audience (Woodside, 2010).

In Marketing, storytelling has been used over the years to discover how to best connect with a target audience. Consumers who are exposed to storytelling are more likely to describe the brand in positive terms and are willing to pay more for the product (Lundqvist et al., 2013). They are also more likely to remain a loyal customer (Pulizzi, 2012; Vincent, 2002).

In an article from Econsultancy, Nick Hammond writes, "The word 'story' is so compelling (and so heavily employed) in marketing, because it evokes emotional reactions rooted in our childhood. Many of the stories told us by our parents were in turn heard from their parents before that and so on (Hammond, 2017). For marketers, being able to evoke an emotional response and strengthen the connection between an organization and its consumers is paramount.

\section{Blogging}

When blogging was first introduced it was not for the purpose of helping an organization tell a story about their brand. Instead, it was for personal use. The first blog was Links.net and was created by Justin Hall in 1994. Hall was a college student and the blog was essentially his personal homepage (WDD Staff, 2011). In these early years, blogging really was for personal use. People would keep journals, thoughts or ideas and others could read them. The primary goal was not customer retention, or engagement, and many companies were not even using blogs.

In 1999 there were 23 blogs. In 2006, that number increased to 50 million (Technorati, 2006). Some of the first blogs to be successful at this time were political blogs. As more people read blogs, more companies began having them (WDD Staff, 2011). Despite the growth of blogs, as more social media 
platforms were created, blogging gained more competition. Reading a blog takes more time than reading a tweet, or watching a snapchat story, but was the intended outcome the same?

Blogging has allowed for companies to craft carefully thought-out stories as a way to inform the public, connect with the media, and get people to think differently (Scott, 2015). Liu and Wu (2011) found that blogs increasingly use storytelling to build customer loyalty. With the increased focus on storytelling, and the lack of ability to craft a thorough story on many newer platforms, it stands to reason blogging is no longer declining and instead growing. This is our first research question: 1 . With the rise in storytelling as a marketing strategy, will the use of blogging increase? If storytelling is a driver of this trend: 2. Will an examination of blogs in the 2018 Fortune 500 show storytelling as a primary structure for posting?

Businesses use storytelling to clarify their brand image or alter current perceptions. Brands that most benefit from this type of marketing are brands whose image or personality may be harder to showcase or ascertain. A 2016 Forbes article discusses how many service firms (accounting, nursing/home care) spend more time utilizing story telling as services are less tangible and therefore harder to advertise (Schmidt, 2016). Based on this, we developed our next research question: 3. Are businesses that would benefit more from storytelling (companies that sell intangible products like insurance or financial institutions) more likely to have a blog?

Originally, the focus in social media was to use blogs in order to have two-way communication between organizations and consumers (Wright \& Hinson, 2008; Briones et al., 2011). Singh and Sonnenburg (2012) argue that storytelling is not set up to be interactive and therefore when using social media, marketers need new strategies to tell a story that can allow for interaction. Has that been done, and can that be done effectively? As storytelling, and blogging are not really conducive for audience participation, are bloggers still focusing on that two-way communication process? Our last research question is as follows: 4. If blogging is increasing in use, are businesses still allowing comments on their blogs?

\section{METHODOLOGY}

Fortune Magazine annually compiles a list of America's largest corporations, aptly named the "Fortune 500" (F500) given their size and wealth. Due to the hugely influential role that these companies play in the business world, studying their adoption and use of social media tools offers important insights into the future of commerce.

The following definition was used to locate 2018 F500 corporations with a social media presence, namely blogs: A company was counted as having a presence if the primary corporation had an active account. This was determined by examining both the date of the last post and the patterns of posting. Typically, a post in the last 30 days qualified for an active account, but in rare cases there were patterns of posting every 45 days. These were considered active as well.

It is worth noting that there is evidence of usage of social media tools such as blogs, Twitter, Facebook, etc. inside branches of these corporations. This research did not look at that subject, but instead focused on public-facing corporate blogs and social media tools as a barometer of social media usage to engage the public.

All corporations were analyzed using multiple steps. First, working from the published 2018 F500 list, all corporate home pages were examined for links to, or mention of, social media accounts. If a link wasn't found on the company's home page, a search was performed using search engines. Any links resulting from these searches were followed and evaluated using the established criteria. This proved to be an effective method since additional social media accounts were located. 


\section{Results}

With the Rise in Storytelling as a Marketing Strategy, Will the Use of Blogging Increase?

When examining whether Fortune 500 companies had blogs, we found that $53 \%$ of companies did in fact have public facing corporate blogs. This is up from 2017, when $42 \%$ of the Fortune 500 had public facing corporate blogs. Since the low of $21 \%$ in 2015, the number of blogs being run at Fortune 500 companies is the highest it has ever been.

\section{FIGURE 2}

FORTUNE 500 CORPORATIONS WITH PUBLIC FACING CORPORATE BLOGS (2013-2018)

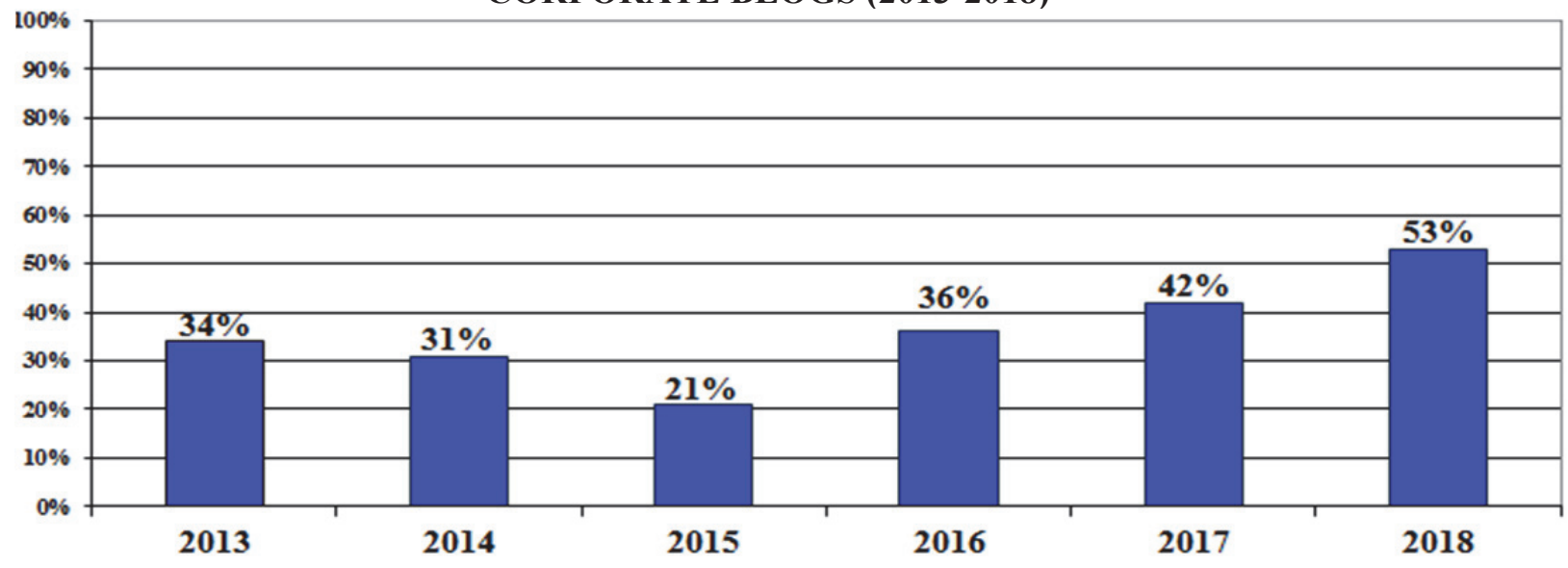

Will an Examination of Blogs in the 2018 Fortune 500 Show Storytelling as a Primary Structure for their Blog Posts?

There are many examples of the use of storytelling among the $53 \%$ of Fortune 500 companies now blogging. Below are a few that demonstrate its use.

Coca-Cola- The blog is called "Unbottled" and is rich in content and aligned with corporate objectives. One of many features tells the story of an Air Force Captain's life-long link to Coca-Cola.

Walmart- The blog is called "Walmart Today" and features a wide variety of content including human interest stories. The company wants to tell the story of its caring for its customers, employees and community. Many posts are written by employees who tell their own authentic stories.

Chase- The blog is called "News and Stories" and is full of personal stories of family and entrepreneurship. There are specific stories with titles like, "How this Millennial woman bought her first house" or "How I got myself credit worthy". Real stories told by Chase customers.

Tyson- The blog is called "The Feed Blog" and posts are written by employees as well as guests. Topics are handled in story form including, "the story behind fast growing chickens". Videos, and animation contribute to make even serious topics something consumers can connect with.

Organizations that Would Benefit More from Storytelling (Companies that Sell Intangible Products Like Insurance or Financial Institutions) Are More Likely to Have a Blog.

The following is a list of industries who do and do not have corporate blogs. Top industries include insurance, utilities and banking, while industries that do not have blogs include chemicals and vehicle parts.

Some of the top industries using blogs in 2018 include:

- Insurance: Property and Casualty

- Utilities: Gas and Electric

- Commercial Banks

- Speciality Retailers 
- Health Care: Insurance and Managed Care

- Insurance: Life, Health

- Financial Data Services

- General Merchandisers

- Semiconductors and Other Electronic Components

In contrast, some of the Fortune 500 industries without corporate blogging include:

- Chemicals

- Motor Vehicles and Parts

- Wholesalers: Diversified

- Diversified Financials

- Aerospace and Defense

- Mining, Crude-Oil Production

- Food Consumer Products

- Pipelines

- Metals

It is evident that industries with more tangible products with a clearer purpose (metals, motor vehicle parts) are less likely to use blogs and need storytelling than service companies like insurance and banking. Utilities and healthcare may be things people are familiar with, but they are also industries whose image needs constant updating as they can be thought of as having a lot of control and influence. Connecting with consumers in these areas is very important.

\section{If Blogging Is Increasing in Use, Are Organizations Still Allowing Comments on Their Blogs?}

All blogs were examined to determine the level of interactivity the blog allowed. This was done by looking at the blog to see if comments were accepted and checking the date of the last post to determine how current it was. In 2018, $106(40 \%)$ of active corporate blogs allowed readers to make comments on their posts, down $11 \%$ from last year. Many of the blogs which allow comments have little to no interaction on the comment threads, which could explain why companies are increasingly doing away with the comment feature on their blogs. While storytelling evokes an emotional response, it does not necessarily stimulate discussion.

FIGURE 3

FORTUNE 500 PERCENT OF BLOGS THAT ALLOW COMMENTS (2014-2018)

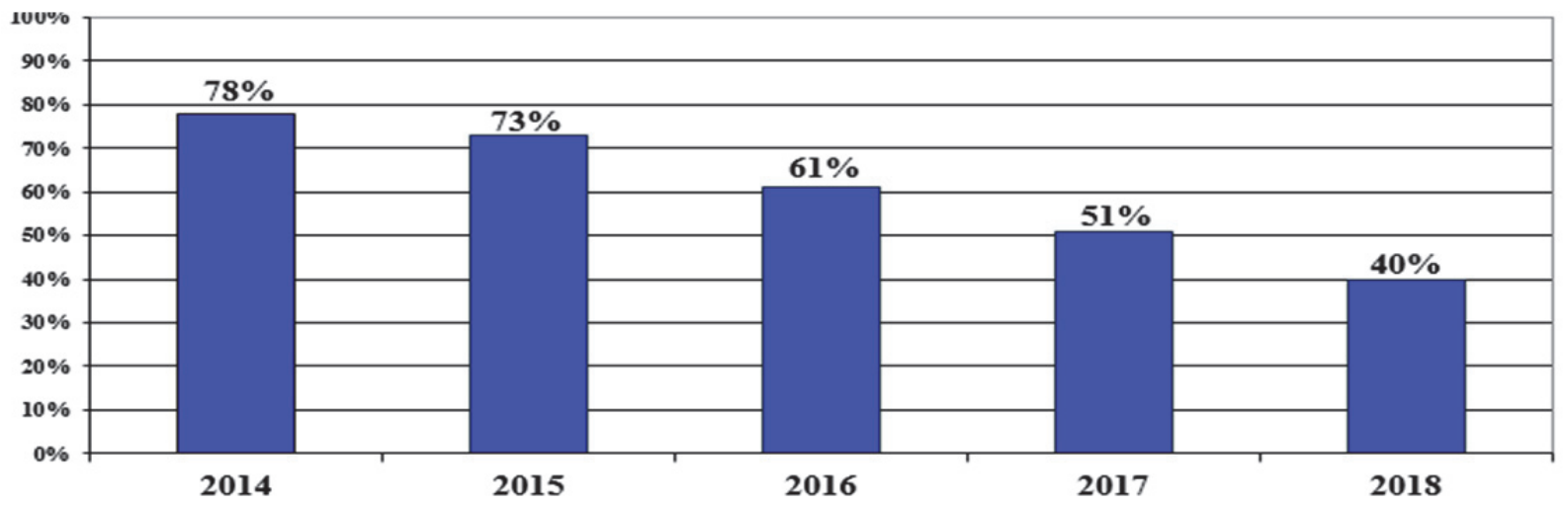




\section{DISCUSSION AND CONCLUSION}

It is obvious that blogging has bounced back, as more companies are blogging than ever before. While blogs were initially personal logs, they morphed into a unique way of conveying a narrative to an audience. In recent years brands have embraced (and been rewarded for) impactful storytelling. A quick look at top blogs including Coca-Cola, WalMart and Anheuser Busch will show stories about employees, consumers, events or experiences in a format that encourages engagement and arouses emotion. We suspect that this increase in the use of blogs for digital storytelling, and the effectiveness of this strategy, has contributed to the number of companies embracing this tool.

The ability to craft a clearer message for your brand is something blogs allow for much more easily than other social media tools. The allowance for comments on the other hand has declined. Because blogs allow for companies to share their story, this does not require two-way communication. Readers do not need to interact, or post and even when they can, are frequently not doing so. This is despite previous research expecting co-creation and interaction to be essential to the success of blogs using storytelling. It is interesting to see how in a three year span such significant changes have taken place.

There are many good reasons for a company to use blogging as part of their social media strategy. Most importantly is the ability of this content rich format to allow for engagement through storytelling. In addition, there is the issue of ownership. A blog on a corporate website is owned and operated by the company without restriction on length, content or tone. This is not true of the microblogging platforms which all impose restrictions.

Future research should analyze the content of blogs vs other social media platforms to see how brand stories are being crafted. Research should also be done on why short, quick, more visual stories, while still popular, have allowed room for blogs to come back into fashion. Are consumers looking for more content, and more in-depth information?

Looking forward, it will be interesting to see where we stand in the social media landscape. Will blogging continue its resurgence? Will storytelling ever really go out of fashion? Only time will tell. For now, blogging is a success story.

\section{REFERENCES}

Briones, R. L., Kuch, B., Liu, B. F., \& Jin, Y. (2011). Keeping up with the digital age: How the American Red Cross uses social media to build relationships. Public relations review, 37(1), 37-43.

Davis, K. M. (2018). How To Solve 7 Major Marketing Challenges Of 2018. Forbes.

Forbes Communication Council. (2018). 18 Continuous Learning Ideas For The ForwardThinking Professional. Forbes.

Ghanadan, H. (2018). Storytelling Is All The Rage, But What Does It Mean For B2B Marketers? Forbes.

Gianatasio, D. (2018). 16 Years After Breaking Our Hearts, Ikea Finally Tells an Abandoned Lamp's Full Story. ADWEEK.

Hammond, N. (2017). The myth of storytelling in marketing and why brands should encourage 'story sharing'. Econsultancy.

Jacobsen, S., \& Barnes, N.G. (2016). The Unfortunate Decline of Blogging Among the Fortune 500: The Downside of Adopting Substitute Innovations. Journal of Strategic Innovation and Sustainability, 11(2).

Levine, Rick et. Al. (2000). The Cluetrain Manifesto: The end of business as usual. Perseus Books. Liu,

H. Y., \& Wu, C. Y. (2011). Storytelling for business blogging: a process on two path model. In e-Education, Entertainment and e-Management (ICEEE), 2011 International Conference on (pp. 60-63). IEEE. 
Lundqvist, A., Liljander, V., Gummerus, J., \& Van Riel, A. (2013). The impact of storytelling on the consumer brand experience: The case of a firm-originated story. Journal of Brand Management, 20(4), 283-297.

McGlothlin, J. (2018). Once Upon a Time: The Power of Story. Baker Brand Communications story telling series. Retrieved from https://www.bakerbrand.com/the-power-of-unique-brand-story/

Monarth, H. (2014). The Irresistible Power of Storytelling as a Strategic Business Tool. Harvard Business Review.

Olenski, S. (2018). 4 Tips For Crafting A Compelling Brand Story. Forbes.

Otremba, L. (2018). How To Take A Content-First Approach When Telling Your Brand's Story. Forbes.

Papadatos, C. (2006). The art of storytelling: how loyalty marketers can build emotional connections to their brands. Journal of Consumer Marketing, 23(7), 382-384.

Pulizzi, J. (2012). The rise of storytelling as the new marketing. Publishing research quarterly, 28(2), $116-123$.

Quesenberry, K. (2014). The Journal of Marketing Theory and Practice, Fall Issue.

Rubel, St. (2010). Why Storytelling is Essential for Business. Fortune Magazine.

The Big Fish Blog. (2012). A Very Brief History of Storytelling. Big Fish Presentations under Presentation Theory.

Technorati. (2006). Weblogs Cumulative- 50 Million weblogs. Tracking the Blogosphere.

Santore, K. (2018). How Good Storytelling Can Keep Your Brand in Its Branded Content. ADWEEK.

Schmidt, L. (2016). Three Unexpected Brands That Are Turning To Storytelling To Drive Recruiting. Forbes.

Scoble, R., \& Isreal, S. (2006). Naked Conversations: How blogs are changing the way businesses talk with consumers. John Wiley \& Sons, Inc.

Scott, D. M. (2015). The new rules of marketing and PR: How to use social media, online video, mobile applications, blogs, news releases, and viral marketing to reach buyers directly. John Wiley \& Sons.

Singh, S., \& Sonnenburg, S. (2012). Brand performances in social media. Journal of interactive marketing, 26(4), 189-197.

Vincent, L. (2002). Legendary brands: Unleashing the power of storytelling to create a winning marketing strategy. Dearborn Trade Publishing.

WDD Staff. (2011). A Brief History of Blogging. Hot Jar.

Whitler, K. A. (2018). 3 Reasons Why Storytelling Should Be A Priority For Marketers. Forbes.

Woodside, A. G. (2010). Brand-consumer storytelling theory and research: Introduction to a Psychology \& Marketing special issue. Psychology \& Marketing, 27(6), 531-540.

Woodside, A. G., Sood, S., \& Miller, K. E. (2008). When consumers and brands talk: Storytelling theory and research in psychology and marketing. Psychology \& Marketing, 25(2), 97-145.

Wright, D. K., \& Hinson, M. D. (2008). How blogs and social media are changing public relations and the way it is practiced. Public relations journal, 2(2), 1-21. 